\title{
"Consumption trends of milk and dairy products in Slovakia and its comparison with other V4 countries"
}

\begin{tabular}{|c|c|}
\hline \multirow{7}{*}{ AUTHORS } & L'ubica Kubicová (iD) \\
\hline & Kristína Predanócyová (iD) \\
\hline & Peter Šedík (i) \\
\hline & Luboš Smutka (i) \\
\hline & \\
\hline & Zdenka Kádeková (iD) \\
\hline & Ingrida Košičiarová (D) \\
\hline ARTICLE INFO & $\begin{array}{l}\text { '́ubica Kubicová, Kristína Predanócyová, Peter Šedík, Luboš Smutka, Zdenka } \\
\text { Kádeková and Ingrida Košičiarová (2021). Consumption trends of milk and dairy } \\
\text { products in Slovakia and its comparison with other V4 countries. Innovative } \\
\text { Marketing , 17(3), 56-73. doi:10.21511/im.17(3).2021.05 }\end{array}$ \\
\hline DOI & http://dx.doi.org/10.21511/im.17(3).2021.05 \\
\hline RELEASED ON & Thursday, 12 August 2021 \\
\hline RECEIVED ON & Tuesday, 01 June 2021 \\
\hline \multirow[t]{2}{*}{ ACCEPTED ON } & Thursday, 01 July 2021 \\
\hline & $(\mathrm{cc}) \mathrm{EY}$ \\
\hline LICENSE & $\begin{array}{l}\text { This work is licensed under a Creative Commons Attribution } 4.0 \text { International } \\
\text { License }\end{array}$ \\
\hline JOURNAL & "Innovative Marketing " \\
\hline ISSN PRINT & $1814-2427$ \\
\hline ISSN ONLINE & $1816-6326$ \\
\hline PUBLISHER & LLC "Consulting Publishing Company "Business Perspectives" \\
\hline FOUNDER & LLC "Consulting Publishing Company "Business Perspectives" \\
\hline
\end{tabular}

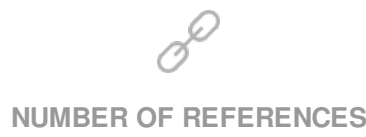

58

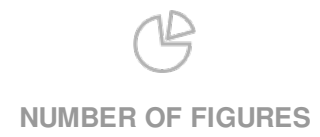

8

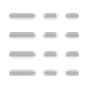

NUMBER OF TABLES

7

(C) The author(s) 2021. This publication is an open access article. 


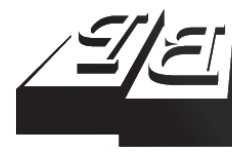

\section{BUSINESS PERSPECTIVES}

LLC "CPC "Business Perspectives" Hryhorii Skovoroda lane, 10, Sumy, 40022, Ukraine www.businessperspectives.org
Received on: $1^{\text {st }}$ of June, 2021 Accepted on: $1^{\text {st }}$ of July, 2021 Published on: $12^{\text {th }}$ of August, 2021

(c) Lubica Kubicová, Kristína Predanócyová, Peter Šedík, Luboš Smutka, Zdenka Kádeková, Ingrida Košičiarová, 2021

Lubica Kubicová, Ph.D., Associate Professor, Slovak University of Agriculture, Faculty of Economics and Management, Department of Marketing and Trade, the Slovak Republic. (Corresponding author)

Kristína Predanócyová, Ph.D. Researcher, Slovak University of Agriculture, AgroBioTech Research Centre, the Slovak Republic.

Peter Šedík, Ph.D., Assistant Professor, Slovak University of Agriculture, Faculty of Economics and Management, Center for Research and Educational Projects, the Slovak Republic.

Luboš Smutka, Ph.D., Professor Czech University of Life Sciences Prague, Faculty of Economics and Management, Department of Trade and Finance, the Czech Republic.

Zdenka Kádeková, Ph.D., Associate Professor, Slovak University of Agriculture, Faculty of Economics and Management, Department of Marketing and Trade, the Slovak Republic.

Ingrida Košičiarová, Ph.D., Associate Professor, Slovak University of Agriculture, Faculty of Economics and Management, Department of Marketing and Trade, the Slovak Republic.

This is an Open Access article, distributed under the terms of the Creative Commons Attribution 4.0 International license, which permits unrestricted re-use, distribution, and reproduction in any medium, provided the original work is properly cited.

Conflict of interest statement: Author(s) reported no conflict of interest
Lubica Kubicová (Slovak Republic), Kristína Predanócyová (Slovak Republic), Peter Šedík (Slovak Republic), Luboš Smutka (Czech Republic), Zdenka Kádeková (Slovak Republic), Ingrida Košičiarová (Slovak Republic)

\section{CONSUMPTION TRENDS OF MILK AND DAIRY PRODUCTS IN SLOVAKIA AND ITS COMPARISON WITH OTHER V4 COUNTRIES}

\begin{abstract}
Milk consumption is a very important part of consumers' daily diet due to its positive health effect. The purpose of the paper is to evaluate the market of milk and dairy products. The paper analyzes the development of milk consumption in V4 countries, which was described by using regression functions. The data were obtained from the statistical offices of chosen countries. Based on the achieved results it was found that in Slovakia and Hungary milk consumption is very low, but in the Czech Republic and Poland consumption is recorded in the range of recommended doses and is sufficient. Looking to the future, based on the described trend of consumption, it is possible to assume that the situation in the Slovak Republic will be accompanied by unfavorable developments and in comparison with other V4 countries, Slovakia will consume the least milk and dairy products per capita. Moreover, a questionnaire survey orientated on the level of milk consumption and consumer behavior was conducted on the sample of 518 respondents. Average Slovak consumers consume daily 1 glass of milk, 20 $\mathrm{g}$ of cheese, $70 \mathrm{~g}$ of curds, and $250 \mathrm{~g}$ of sour-milk or other dairy product. Depending on the level of consumption, 3 consumer segments were defined for which different consumer behavior was identified, especially in the issue of factor assessment. In general, however, it is concluded that the quality and price of milk and dairy products are crucial for consumers to make their choice.
\end{abstract}

Keywords

consumer, factors affecting consumption, food demand, recommended doses, regression, segmentation

JEL Classification Q13, M30, M31

\section{INTRODUCTION}

Milk and dairy products can be included among the basic food groups that are consumed by households in Slovakia as well as within other V4 countries. The necessity of milk consumption can be seen in the positive health effects, especially in the possibility of preventing osteoporosis. At present, great emphasis is placed on the lifestyle of consumers and constant changes have a positive effect on increasing dairy products consumption, especially with added value, mainly sour-milk products and acidophilic dairy products. In connection with the current situation resulting from the pandemic of the COVID-19, milk consumption is becoming vital, as it has been shown to have positive effects on consumers' immunity and its strengthening. Thus, it is essential to constantly educate and inform consumers about the necessity of consumption. Positive effects of milk and dairy products become a prerequisite for regular consumption. However, Slovakia has recorded low milk consumption compared to the recommended doses, and in comparison with other countries, the situation in Slovakia is not satisfying. Moreover, in comparison with other countries, the situ- 
ation in Slovakia is alarming and at present, there are not elaborated scientific studies that concern the given issue. The paper points out the development of milk consumption in the period from 1990 to 2019 in Slovakia with the emphasis on comparison with other V4 countries and examines the profile of consumers classified into segments depending on the level of consumption.

\section{LITERATURE REVIEW}

Milk takes an irreplaceable place in human nutrition in the long run, as confirmed by Maitah and Smutka (2012), Visioli and Strata (2014), Kubicová et al. (2019), Górska-Warsewicz et al. (2019), Kharin (2019), and Janecká et al. (2019). However, in the case of a child consumer, milk is an essential food for healthy development and growth (Rozenberg et al., 2016; Dror \& Allen, 2014; Žáková Kroupová et al., 2020).

Milk has irreplaceable importance due to its biological value. Milk and dairy products are characterized by their balanced composition and a wide range of components that are essential for proper and preventive nutrition (Pereira, 2014). Milk belongs to complex foods due to its nutritional value and rich content of vitamins and minerals (Nicklas et al., 2009; Finete et al., 2013; Guetouache et al., 2014; Keresteš, 2016). These nutritional sources can make a significant contribution to food safety and consumer health (Garcia et al., 2019).

The main positive effects of milk and dairy products consumption are resulting from the individual components, which are shown in Table A1 (Appendix A).

The most important component is milk protein (Kala et al., 2019) that has a positive effect on the construction of the organism, as well as on the provision of basic life functions. This may be due in particular to the content of amino acids (Kanwar et al., 2009), which can have a positive impact on eliminating the negative effects of malnutrition (Michaelsen et al., 2011). The beneficial effect of milk proteins on blood pressure has also been demonstrated (Pfeuffer \& Watzl, 2018). Lack of protein in the diet can cause significant bone deterioration and osteoporosis (Bonjour, 2005; Prentice, 2014).

Another component is milk fat, which is a key energy source (Guetouache et al., 2014) and con- tains certain components having functional significance (Gasmalla et al., 2017). Milk fat is important during the absorption of $\mathrm{A}, \mathrm{D}, \mathrm{E}$, and $\mathrm{K}$ vitamins. Vitamins soluble in milk fat are very significant because they have antioxidant properties, thus also acting against viruses and bacteria (Król et al., 2020). Carbohydrates can be considered as another milk component. The primary component of carbohydrates is milk sugar (lactose), which is mainly attributed to energy (Gambelli, 2017).

Minerals are another important component. Calcium and phosphorus are significantly involved in the growth of bones and teeth, especially the children ones (Górska-Warsewicz et al., 2019; Thorning et al., 2016; Rizzoli, 2014), but have favorable effects on the metabolic processes (Gasmalla et al., 2017). Magnesium is an important mineral that has a key role in various processes of a physiological character. Iron and copper can be included among other minerals that have a beneficial impact on health (Zamberlin et al., 2012).

The next component is vitamins, especially vitamin $\mathrm{D}$, which has a beneficial effect on the bones and prevent osteoporosis (Gasmalla et al., 2017), protect the body against high blood pressure (Moore et al., 2005), and prevent overweight (Thorning et al., 2016; Zemel et al., 2004). Vitamin D also helps in the treatment of disorders such as fibromyalgia, diabetes, sclerosis, and rheumatoid arthritis (Jesus et al., 2013).

Based on the proven positive effects, it can be stated that the consumption of milk and dairy products brings beneficial health impacts to consumers of all ages. Nowadays, consumers increasingly focus on value-added products and look for fermented dairy products, such as acidophilic milk, buttermilk, kefir, or probiotic dairy products (Muehlho et al., 2013). The mentioned products can be classified as functional foods (Smutka et al., 2016) and have become very popular among 
consumers, mainly consumers with special consumption habits (Gasmalla et al., 2017; Džupina et al., 2016; Polakevičová, 2015). Milk and dairy products consumption is significantly influenced by the use of a wide range of distribution channels and milk is currently available in every grocery, as well as in health food stores, food stores aimed to milk and dairy products and moreover milk is also distributed by other ways, such as vending machines. Other marketing tools, which are applied by producers and sellers, also play a significant role in milk and dairy products consumption, and marketing communication tools are mostly used (Bielik et al., 2020; Krivošíková et al., 2019; Horská et al., 2020; Kubicová et al., 2019; Nagyová et al., 2020).

\section{AIMS}

The main aim of the paper is to evaluate the current situation in the market of milk and dairy products. The aim was divided into two sub-aims. The first one is to examine the development of milk and dairy products consumption in Slovakia and compare these values with other countries of the Visegrád Group. The second one is to identify consumer behavior on the milk market of Slovakia, define the segments of milk and dairy products consumers, as well as to examine key factors affecting the level of consumption.

To fulfill aims the following statistical hypotheses were formulated:

- there exist different segments depending on the level of consumption;

- Slovak consumers rank the reasons for low consumption differently;

- there are differences between consumers in individual segments depending on demographic characteristics;

- there is a relationship between the key reason for consumption and consumer segments;

- there are differences in factors determining the level of consumption in the various segments.

\section{METHODOLOGY}

Secondary data were necessary for processing the development of milk and dairy products consumption in the countries of the Visegrád Group. Data were obtained from the statistical offices of the Slovak Republic, the Czech Republic, Hungary, and Poland, and became the basis for examining the development of the consumption trend. The consumption trend was described by regression functions (linear, quadratic, cubic, and quantic functions) and forecasted until 2022.

Linear function is expressed by the formula (1)

$$
y_{i}=\beta_{0}+\beta_{1} x_{i}+\varepsilon_{i}, \quad i=1,2, \ldots, n .
$$

Quadratic function is expressed the formula (2)

$$
y_{i}=\beta_{0}+\beta_{1} x_{i}+\beta_{2} x_{i}^{2}+\varepsilon_{i}, \quad i=1,2, \ldots, n .
$$

Cubic function is expressed by the formula (3)

$$
\begin{aligned}
& y_{i}=\beta_{0}+\beta_{1} x_{i}+\beta_{2} x_{i}^{2}+ \\
& +\beta_{3} x_{i}^{3}+\varepsilon_{i}, \quad i=1,2, \ldots, n
\end{aligned}
$$

Quantic function is expressed by the formula (4)

$$
\begin{aligned}
& y_{i}=\beta_{0}+\beta_{1} x_{i}+\beta_{2} x_{i}^{2}+\beta_{3} x_{i}^{3}+ \\
& +\beta_{4} x_{i}^{4}+\varepsilon_{i}, \quad i=1,2, \ldots, n,
\end{aligned}
$$

where $y_{i}-i$-th observed value of the explained variable; $\beta_{0}, \beta_{1}$ - unknown parameters of the regression model, $x_{1}-i$-th value of the explanatory variable, $\varepsilon_{i}-$ number of observations.

Mathematical methods and calculation of the coefficient $\bar{k}$ were used in the processing of secondary data.

$$
k=\sqrt[n-1]{k_{2} \cdot k_{3} \cdot \ldots \cdot k_{n}}
$$

Primary data were necessary for finding the consumer behavior in the milk market and for identifying consumer segments according to the level of milk and dairy products consumption. Primary data were obtained from the consumer survey realized by the questionnaire on the sample of 518 Slovak consumers in 2018. To obtain relevant data Slovak consumers were interviewed by an elec- 
tronic form and the survey was conducted by the snowball sampling method. The structure of respondents involved in the survey is stated in Table A2 (Appendix A).

The collected data on daily consumption of milk, cheese, cottage cheese, cream, yogurt, and other sour-milk products were converted to the annual consumption of individual dairy foods in kilograms. Then it was compared with the annual recommended consumption. The obtained data became a prerequisite for creating consumer segmentation. The data from the questionnaire were processed by using Microsoft Excel and assessed by such statistical programs as IBM SPSS and XL Stat. The established hypotheses were tested by using the Chi-square contingency test, Friedman test, and Nemenyi method, as well as using multidimensional statistical methods, namely twostep cluster analysis, and Categorical Principal Component Analysis (CATPCA).

\section{RESULTS AND DISCUSSION}

In the long period, the consumption of milk and dairy products in Slovakia is characterized by a declining trend, but in recent years there has seen a gradual increase and the current level of consumption reaches the level of 1993. It is important to emphasize that it still does not meet products at the level of recommended doses (209-240 kg). This level was reached only in the first two observed years. Developments in consumption were accompanied by a slight upward trend and ranged from $152.4 \mathrm{~kg}$ and $226.3 \mathrm{~kg}$ per capita and year, which implies an average decrease of $0.93 \%$ ( $\mathrm{k}^{\prime}=$ 0.009907). A rapid decrease in consumption was recorded in 1992 and 1993. Since then, consumption has gradually decreased and the lowest level of consumption in the last 30 years was recorded in 2006 when the average consumption per Slovak consumer was $152.4 \mathrm{~kg}$. The largest increase in consumption was recorded in 2010 when the consumption increased to $162.8 \mathrm{~kg}$, which meant an increase of $9 \mathrm{~kg}$ compared to 2009. Since 2011, the goal was to increase consumption, but despite efforts, consumption is currently only $172.8 \mathrm{~kg}$ and lags behind the recommended dose interval by approximately $21.5 \%$. To describe the development trend of the total milk consumption in Slovakia, a cubic function (6) with the following parameters was chosen

$$
\begin{aligned}
& q_{t}=225.5-12.259 \cdot t+ \\
& +0.636 \cdot t^{2}-0.0095 \cdot t^{3} \\
& R^{2}=0.8367 .
\end{aligned}
$$

In the dependence of this function, it was assumed with a view to the future of three years that the milk consumption would reach approximately the same level as at present without significant fluctuations. Annual milk and dairy products consumption may increase slightly, but by 2022 it will still be around $170 \mathrm{~kg}$ per consumer, thus not meeting the level of recommended doses. If these preconditions are met, Slovakia will achieve the worst results in consumption within the V4 countries.

The situation in the Czech Republic with the development of milk and dairy consumption was more favorable and Czech consumers on average consumed the largest quantities of milk and dairy products compared to consumers within the V4 countries. In the long run, however, there is a gradual declining trend in consumption, as evidenced by the average annual decline of $0.1 \%$ per year in the period 1990-2019. In 1990, annual consumption was recorded at $256.1 \mathrm{~kg}$ per Czech consumer, which represented the highest achieved value in the period. Subsequently, the annual consumption decreased until 1995, when it reached a level of only $187.8 \mathrm{~kg}$, which lagged consumption by almost $15 \%$ in comparison with the recommended doses. Since 1996, consumption has gradually increased and since 2000, consumption has been recorded in the range of recommended doses. In recent years, the positive developments in consumption are largely contributed to support programs, which have a strong positive impact on consumption (comparing to Slovakia), and current annual consumption is $249.0 \mathrm{~kg}$ per capita. The consumption trend in the Czech Republic was described through the quintic function (7), which acquires the parameters

$$
\begin{aligned}
& q_{t}=301.36-45.853 \cdot t+6.3979 \cdot t^{2}- \\
& -0.3573 \cdot t^{3}+0.0088 \cdot t^{4}-0.00008 \cdot t^{5}, \\
& R^{2}=0.9397 .
\end{aligned}
$$

Based on the stated function, favorable development in the consumption by Czech consumers 
with a view to 2022 could be estimated. In the next three years, consumption is likely to increase to the level reached at the beginning of the reference period, significantly exceeding the recommended dose range.

Poland is another country that was monitored and compared. In comparison with Slovakia, it can be stated that the level of consumption in the first observed year in the period from 1990 to 2018 was approximately the same, while in Poland the recorded consumption was $231.6 \mathrm{~kg}$, which exceeded recommended doses. However, in the following years, the annual consumption gradually decreased and in 2005 reached a level of only 178.2 $\mathrm{kg}$ per Polish consumer and lagged by almost $20.0 \%$ compared to the recommended doses. The situation has gradually started to improve since 2006 and has been growing until now. It can be declared that since 2013, the average consumption of milk and dairy products in Poland has been in the range of recommended doses. In 2018, the consumption of milk and dairy products was recorded at the level of $227.6 \mathrm{~kg}$ per capita, which exceeds the recommended doses by almost $4 \%$. From a long-term perspective, it can be concluded that the consumption is relatively constant, as evidenced by an average annual decline of only $0.06 \%$, but in the last 30 years accompanied by fluctuations in the form of a relatively significant decline in the race. Over the last 10 years, it is possible to record a growing trend in consumption. Based on the data, the consumption trend in Poland was expressed by a quadratic function (8) with the following parameters

$$
\begin{aligned}
& q_{t}=235.04-6.8699 \cdot t+0.2357 \cdot t^{2}, \\
& R^{2}=0.8991 .
\end{aligned}
$$

With a view to 2022, it is possible to assume a positive development in the consumption of milk and dairy products by Polish consumers based on the presented function. It is probable that if consumption develops at a pace as in the last 7 years, consumption can reach a level of more than $250 \mathrm{~kg}$ per capita and year, which will approach the level registered in the Czech Republic.

The last country to be addressed for comparison of milk consumption in the period 1990-2018 is Hungary. Based on the development of consump- tion, it can be stated that Hungary achieved the worst results in consumption per capita. In any of the observed years, the consumption did not fulfill recommended doses. The highest consumption was recorded in 1990 and annual consumption was recorded at a level of only $169.9 \mathrm{~kg}$ per Hungarian consumer. Since then, it has been possible to state a fluctuating course in consumption with an average annual decrease of $0.08 \%$. The lowest annual consumption was recorded in 1995 at a level of $132.1 \mathrm{~kg}$, which represented only $60 \%$ of the recommended doses. Since that time, the consumption with slight fluctuations increased gradually and now reached a level comparable with the beginning of the reporting period. In 2018 , consumption was recorded at $166.2 \mathrm{~kg}$, but compared to the recommended doses it is still lagging by almost $25 \%$. It is important to note that since 2004, consumption in Hungary has been at approximately the same level as in Slovakia. The consumption trend in Hungary was expressed through the quintic function (9), which acquires the parameters (4)

$$
\begin{aligned}
& q_{t}=192.54-20.694 \cdot t+2.9313 \cdot t^{2}- \\
& -0.1715 \cdot t^{3}+0.0044 \cdot t^{4}-0.00004 \cdot t^{5} \\
& R^{2}=0.5509
\end{aligned}
$$

Come out the above function, with a view to 2022, it is possible to assume a favorable pace of development of consumption in Hungary. It is assumed that the consumption will increase, and in 2022 it could reach the highest level since 1990. However, annual consumption at around $180 \mathrm{~kg}$ per capita will still not meet recommended doses (Figure 1).

Thus, it can be concluded that the situation in the Slovak Republic is unfavorable in comparison with the V4 countries, and with a view to the future, it is possible to assume the least positive development among V4 countries. From Figure 2, it is possible to identify the main trends on the Slovak dairy market related to the consumption development and their comparison with the recommended doses. It can be stated that in the last 30 years the consumption has decreased, while in 1990 it exceeded the recommended amount, in 2019 it lagged by more than $20 \%$. The negative development trend was mainly due to drinking milk, which in 2019 reached more than $20 \%$ overconsumption, while in 2019 up to $51 \%$ under consumption was record- 
Source: Statistical Office of the Slovak Republic (2020), Statistical Office of the Czech Republic (2021), Hungarian Central Statistical Office (2020), Statistics Poland (2021).

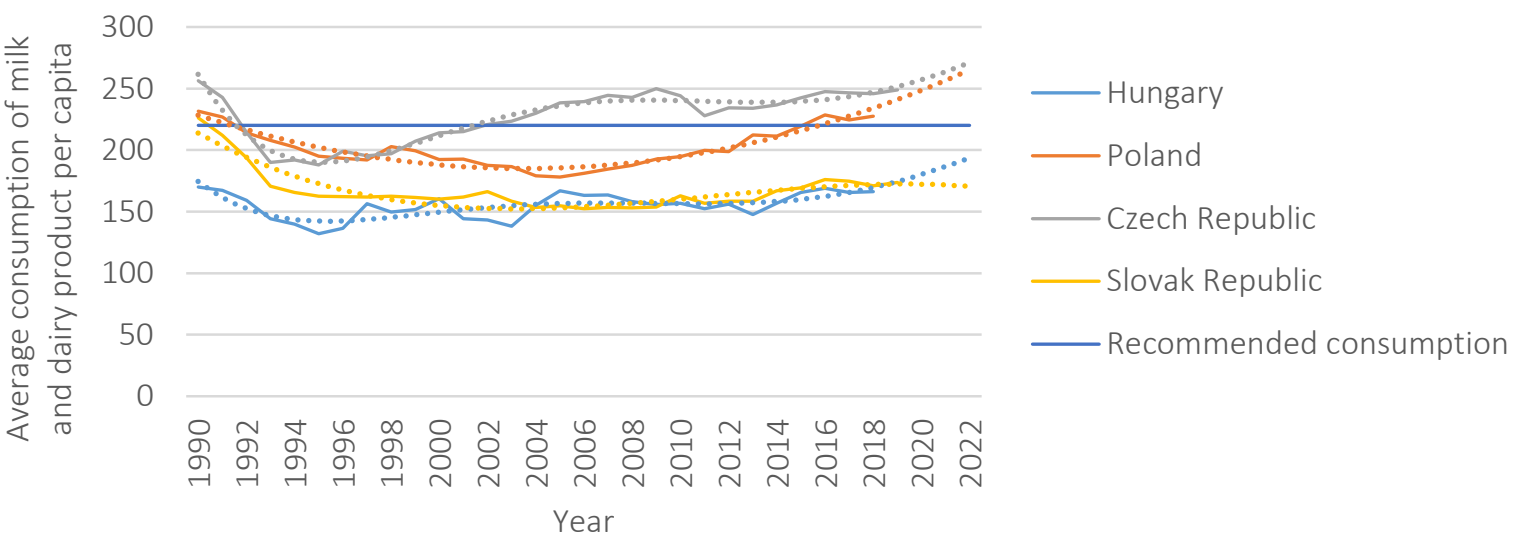

Figure 1. Comparison of the average total consumption of milk and dairy products in the Slovak Republic, the Czech Republic, Poland, and Hungary - per capita and year in kg

ed. Despite this, the unfavorable development of consumption was positively affected by the growing consumption of cheese and sour-milk products. Although the situation is gradually improving, the cumulative consumption of milk and dairy products is at a lower level than in the past. Favorable developments could be affected by increasing consumer disposable income, which is conditional in particular on the purchase of value-added dairy products, consumer awareness of the need to consume milk and dairy products, and an expanding range of dairy products. The dairy market can also be significantly affected by the growing consumption of high value-added dairy products, which are healthy and functional foods. It is also necessary to highlight aspects that may slow down the growing trend in consumption. These are, in particular, the rising consumer prices and the effects on consumers' disposable income resulting from the current situation caused by the
COVID-19. Other determinants influencing the negative development are the lack of information, or the expansion of the vegan way of life, and the preference for milk of plant origin.

As a result, the reasons for lower milk and dairy products consumption in Slovakia were found, in comparison with the recommended doses, and thus in comparison with the past, when a sufficiently high consumption of the monitored food group. Consumers were asked to rank 5 reasons for low milk consumption, with 1 being the most significant reason and 5 - the least significant reason. According to the results, it can be stated that consumers consider the higher price of these products compared to disposable income and lower product quality to be key reasons for low consumption. Based on the Friedman test ( $p$-value $=<0.001$ ), the existence of differences in the assessment of key

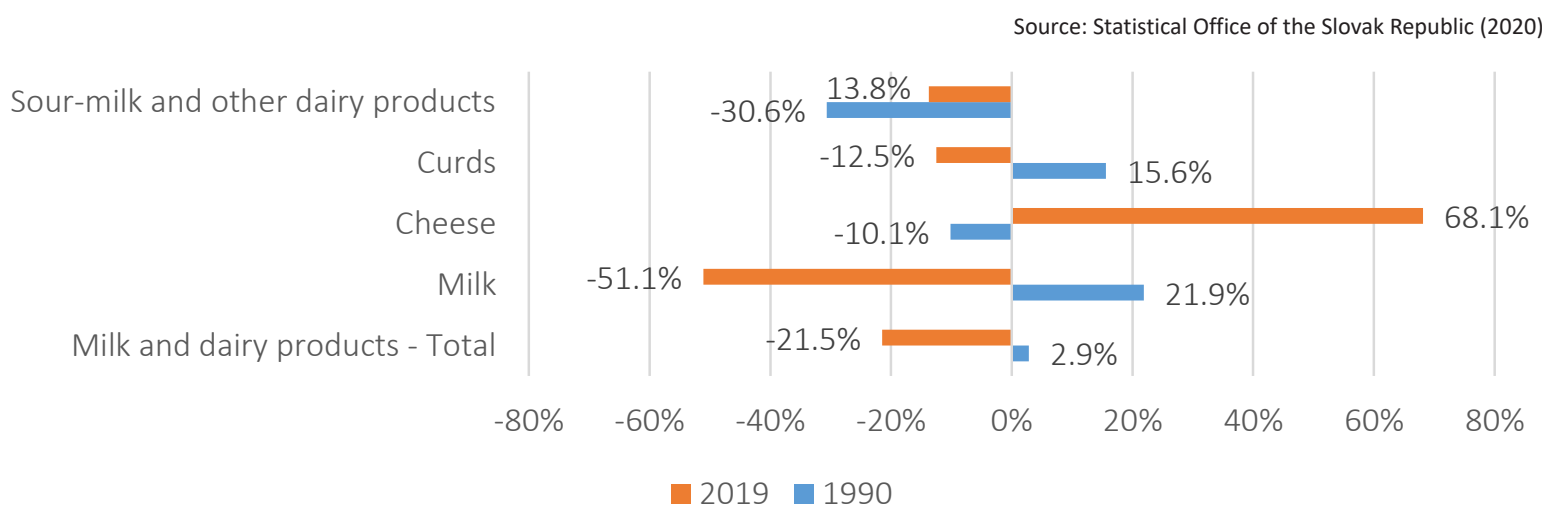

Figure 2. Comparison of recommended and real consumption of milk and dairy products in the Slovak Republic in 1990 and 2019 
Source: Authors' elaboration.

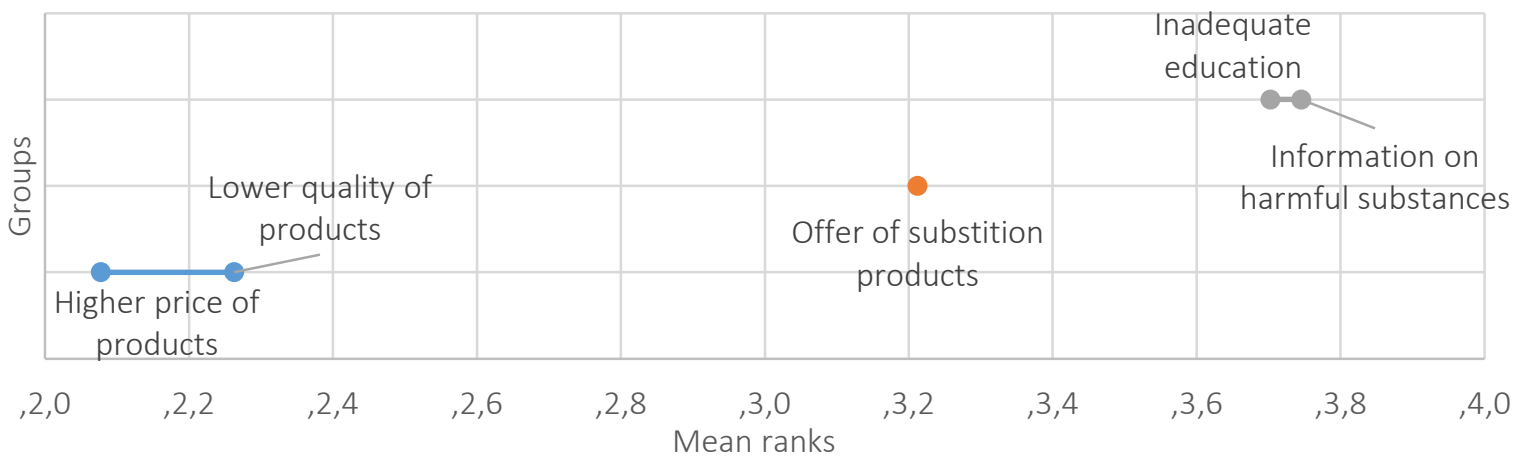

Figure 3. Differences in the assessment of the reasons for low consumption of milk and dairy products

reasons for low consumption was identified. By applying the Nemenyi method, it is possible to add that higher prices and lower quality are the main reasons for low consumption (Group A). Another reason is the expanded range of substitute products (Group B) that eliminate consumption of milk and dairy products. The last group of reasons (Group C) is the lack of consumer information, as well as the claim that milk contains harmful substances and can cause negative health effects. Differences in the evaluation by Slovak consumers were demonstrated between the mentioned groups (Figure 3). In addition, according to Willett and Ludwig (2020), lactose intolerance limits milk consumption.

Milk and dairy products consumption was also evaluated by Slovak consumers. The results showed that Slovak consumers are among the consumers of milk and dairy products, as only $0.4 \%$ of consumers do not consume milk and dairy products. Xu et al. (2019) emphasized that 9\% did not consume milk, further highlighted that more than $90 \%$ of consumers consume this type of food and $73 \%$ of them drink milk and consume dairy products daily, and $20 \%$ of consumers prefer consumption several times a week. This survey aimed at consumers in the Slovak Republic was also focused on identifying the amount of consumption of milk and dairy products, specifically cheeses, curds, sour milk, and other dairy products. This was achieved based on detailed recalculations of portions of individual types of selected food products. Consumers determined the average daily quantities of milk and dairy products consumed in portions, which were then converted into kilograms and year (Figure 4).
Taking into account these results, it can be declared that milk and dairy products consumption is at a sufficient level, as $50.4 \%$ of consumers report consumption in the range of recommended doses or even higher. Negative consumption was recorded by $14.1 \%$ of consumers who do not reach the recommended interval. In terms of distribution between individual types of dairy products, it can be stated that drinking milk consumption is unfavorable and insufficient consumption was recorded by more than $60 \%$ of consumers, which represents annual consumption of less than 91 $\mathrm{kg}$ per capita. A sufficient amount of milk consumption is achieved by only $37.3 \%$ of consumers. Another type of dairy product examined was cheese, in which $94.0 \%$ of consumers reached the recommended dose range, which represents annual consumption of more than $6.9 \mathrm{~kg}$ per capita. A positive trend was also recorded in curds consumption, where more than $65 \%$ of consumers reach the interval of annual recommended doses at the level of $3.2 \mathrm{~kg}$. Surprisingly, excessive consumption of sour-milk and other dairy products has been reported in more than $90 \%$ of consumers, representing more than $16 \mathrm{~kg}$ per capita and year. Guiné et al. (2020) dealt with the adequacy of consumption and the results revealed that, for the whole sample, a huge majority of participants have low milk consumption (93.8\%), low cheese consumption (93.8\% low, and only 5.9\% moderate) and consumption of yogurts is again low (91.5\%).

In the context of obtained results can be stated that the consumers who participated in the questionnaire showed overall sufficient consumption, but there is a clear preference for cheese and sour- 
Source: Authors' elaboration.

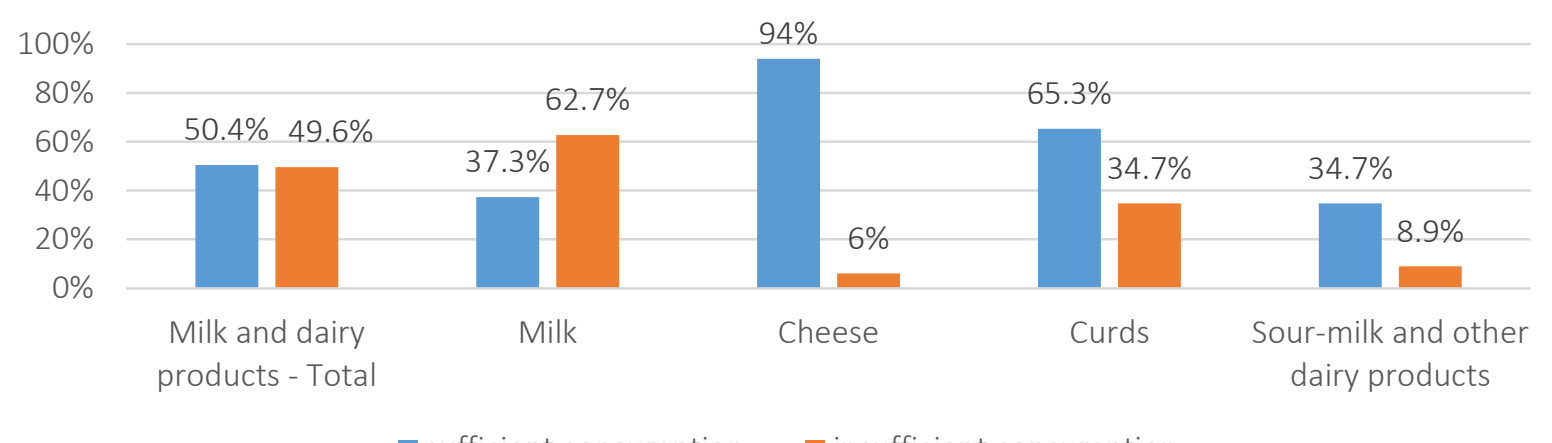

a sufficient consumption $\quad$ insufficient consumption

Figure 4. Annual consumption of milk and dairy products

milk products, which may be due to product added value as well higher positive effects on health. It is possible to note the average daily consumption, which consists of 1 glass of milk, $20 \mathrm{~g}$ of cheese, 70 $\mathrm{g}$ of curds, and $250 \mathrm{~g}$ of sour-milk product, whether it be yogurt, probiotic drinks, kefir, or milk rice. Surveys focusing on consumption levels are currently absent. Ahmadi Kaliji et al. (2019) reported yogurts, milk, and cheeses as the most consumed products. Haas et al. (2019) aimed at the frequency of milk consumption during one week and it can be stated that the majority of involved consumers prefer consumption of milk every week, and the frequency of consumption was "1-2 times" (30\%), “3-4 times" (33.5\%), and "5-6 times" (19.4\%) per week.

In terms of identified consumption of Slovak consumers involved in the survey according to the recommended doses, 3 segments were created depending on the level of consumption of milk and dairy products. The distribution of consumers in terms of the amount consumed in comparison with the recommended doses is given in Table A3 (Appendix A).
The first segment included $34.7 \%$ of the total number of respondents. It can be stated that up to 55\% of consumers in this segment do not achieve consumption of milk and dairy products in terms of recommended consumption level (Figure 5). This fact is mainly due to the low consumption of drinking milk and none of the consumers did not achieve annual milk consumption of $91 \mathrm{~kg}$. Consumption, in particular cheese, curds and sour milk, and other dairy products, is sufficient for all consumers and contributes significantly to the total consumption of the food group in question. The average consumer in the examined segment consumes $0.15 \mathrm{l}$ of milk, $20 \mathrm{~g}$ of cheese, $110 \mathrm{~g}$ of cottage cheese, and $280 \mathrm{~g}$ of sour-milk or other dairy product per day.

The second segment represents $25.9 \%$ of consumers involved in the consumer survey. This segment includes up to $98.8 \%$ of consumers who reach or exceed the recommended amount of milk and dairy consumption (Figure 6). This indicates that only those consumers who consume a sufficient amount of drinking milk, cheese, cottage cheese, and sour-milk products are included in this seg-

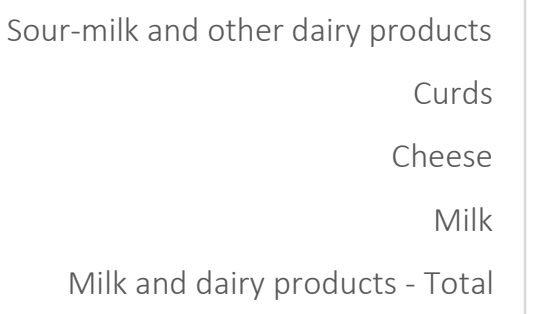

Source: Authors' elaboration.

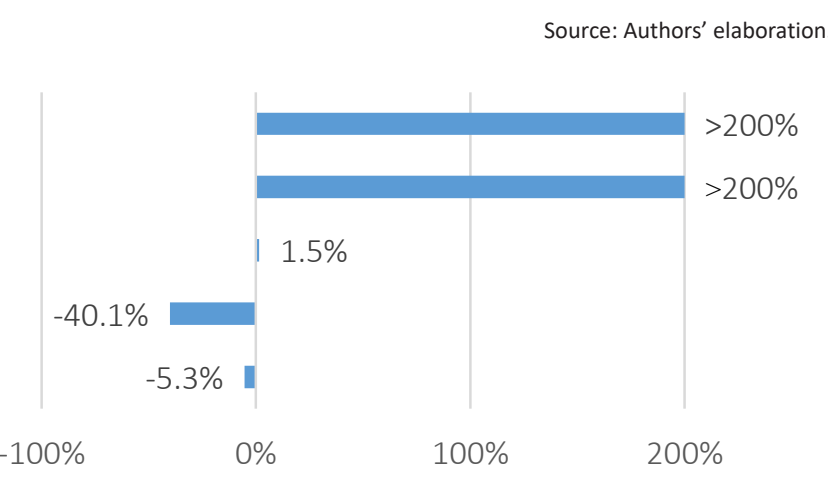

Figure 5. Average consumption for segment 1 


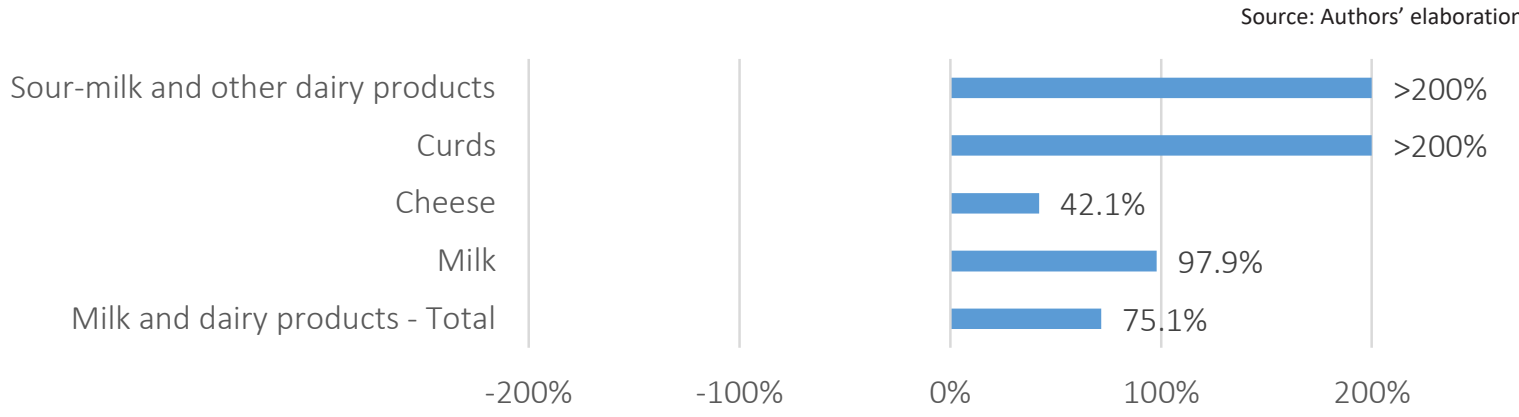

Figure 6. Average consumption for segment 2

ment. 2.2\% of consumers who do not reach the interval of the recommended amount at the level of min. $206 \mathrm{~kg}$ could be caused by the fact that only selected dairy products were examined in more detail. Products such as butter and cream have not been taken into account in this case and may represent a deviation from real consumption, which lags behind only about $5 \%$ of the recommended doses for the consumers concerned. The average consumer from this segment consumes 0.51 of milk, $250 \mathrm{~g}$ of cheese, $125 \mathrm{~g}$ of cottage cheese, and $375 \mathrm{~g}$ of sour-milk product per day.

The last segment represents almost $40 \%$ of all consumers involved in the consumer survey, but up to $76 \%$ of them do not achieve the consumption of milk and dairy products at the level of the recommended dose interval (Figure 7). This segment is mainly characterized by cheese and sour-milk products consumption, which brings consumers from this segment closer to the average consumer involved in the survey. Most consumers in this segment consume cheese $(84.4 \%)$ and sour-milk products $(77.5 \mathrm{~kg})$. On the other hand, consumers have lower consumption of drinking milk (77.1\%) and cottage cheese (88.5\%). The average consumer from the examined segment consumes $0.2 \mathrm{l}$ of milk, $150 \mathrm{~g}$ of cheese, $10 \mathrm{~g}$ of curds, and $165 \mathrm{~g}$ of sour-milk product per day.

Table A4 (Appendix A) shows the structure of consumers in individual segments in terms of demographic criteria, which are the basis for describing segments, and the dependencies between defined segments based on the applied Chi-square contingency test were identified. Based on the data, it is possible to define that in all three segments women predominated as consumers. This also resulted in non-confirmation of the existence of differences between segments ( $p$-value $=0.532$ ). In terms of age, the differences between the segments ( $\mathrm{p}$-value $=0.683$ ) and consumers were also not confirmed, especially in the case of young people under the age of 25. Education did not affect the distribution of respondents in segments $(\mathrm{p}$-value $=0.494)$ and consumers were mainly with secondary and tertiary education. According to the aspect of the residence, no differences between segments were identified ( $p$-value $=0.752$ ), but in the second and third segments urban consumers predominated, while in the first segment they were rural consumers. There were differences between segments in the number of household members ( $\mathrm{p}$-value $=$ 0.036 ) and it can be stated that in the third and first segment more than $60 \%$ of consumers were

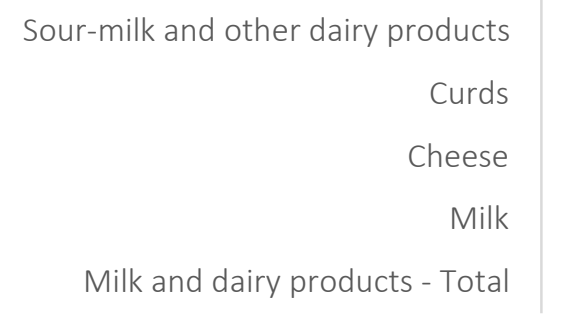

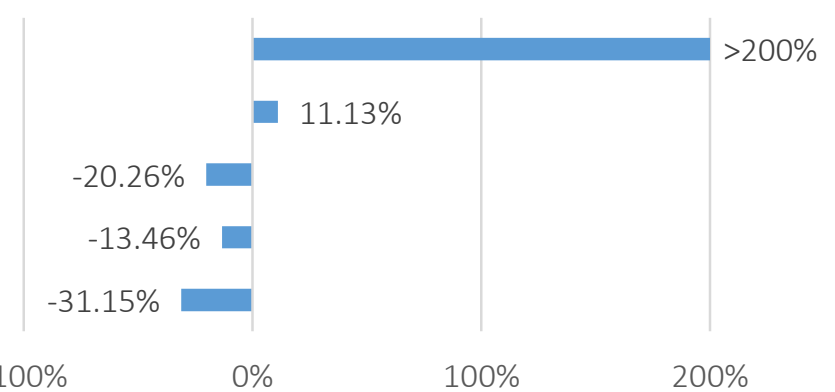

$\begin{array}{lll}-100 \% & 0 \% & 100 \%\end{array}$

Figure 7. Average consumption for segment 3 
households with 3 or 4 members, while in the second segment it was $50 \%$. An interesting finding was that in the second segment there was only $1.5 \%$ of households with 1 member, but up to $15.8 \%$ of households with at least 5 members. From the point of view of the economic status, it is possible to state a similar grouping of consumers in segments regardless of differences ( $\mathrm{p}$-value $=0.337$ ) and the largest part of consumers was employed. In terms of household income in which consumers live and respondents' income, no differences in segments were identified ( $p$-value $=0.336 ; p$-value $=0.216$ ) and most consumers live in households with incomes ranging from EUR 1,000 to EUR 2,000 , with their income is in most cases in the amount of EUR 400 to EUR 1,200 per month.

The results show that the main reasons for consumption among consumers in the first and second segments are mainly taste, rational diet, and nutritional value. Kapaj (2018) emphasized that consumers who consider milk to be a very good source of nutrients are characterized by higher consumption of milk and dairy products. However, in the third segment, taste, a habit since childhood, and rational diet are decisive for consumers. In the context of this, statistical differences between the segments were identified as demonstrated by the application of the Chisquare contingency test ( $\mathrm{p}$-value $=0.0016$ ) (Table A5, Appendix A). According to Kurajdová et al. (2015), taste, health, and utility or usefulness can be considered as the three most important reasons that motivate Slovak consumers to buy milk.

As part of the study, key factors that influence the level of consumer consumption were examined. Consumers rated selected factors on a scale from 1 to 4 , with 1 being the most significant factor and 4 the least significant one.

The hidden relationships between the examined factors were identified. Based on the obtained results and the application of Categorical Principal Component Analysis (CATPCA), three latent components were created to determine the level of consumption (Table A6, Appendix A). The first component consists of composition, quality, nutritional data, country of origin, and producer. As these factors can be considered as determining the quality, this group of factors can be called a "quality factor".
The second component is factors such as the package appearance, product promotion, or package size. These aspects are considered to be complementary and are often associated with marketing activities. For this reason, this component is named as a "factor supporting sales and consumption."

The third component is composed of price and durability factors. The link between these two factors is significant and may determine that the price of an end-of-life product will be lower than a product that has only recently been manufactured and established in the market. For this reason, this factor is called a "price vs. cost factor". Factors affecting the purchase and consumption were also addressed by Alwis et al. (2009), who stated that the health aspect, the price level, and the product availability were identified as the main criteria. Grebitus et al. (2007) indicated that the key factors for the decision-making process in milk purchase are shelf-life, freshness, and price; and the least important determinants are additional information, for example, recipes and nutrition. Boniface et al. (2012) emphasized that information related to price is very important for consumers and noted that consumers have to pay more for the high quality of milk and dairy products. Špička (2013) emphasized that with the deteriorating financial situation, consumers buy cheaper dairy products sold under private labels. On the other hand, it is necessary to highlight that consumer prices are influenced by the existence of retail chains and they can be expressed as the result of their market competition (Matulová et al., 2010).

In the context of the achieved results and the applied Friedman test and the subsequent Nemenyi method, it was stated that there are differences in factors assessment. The key factor is the quality (Group A), while the other main aspects are composition, durability, and price (Group B). Other less important factors affecting the consumption are nutritional data, country of origin (Group C), as well as package size, and producer (Group D). The country of origin factor is in both groups $C$ and $\mathrm{D}$, from which it can be deduced that the evaluation of the factor did not show a statistical difference with other factors, which are in group C and group D. However, there are statistical differences in evaluation between group $\mathrm{C}$ and group 


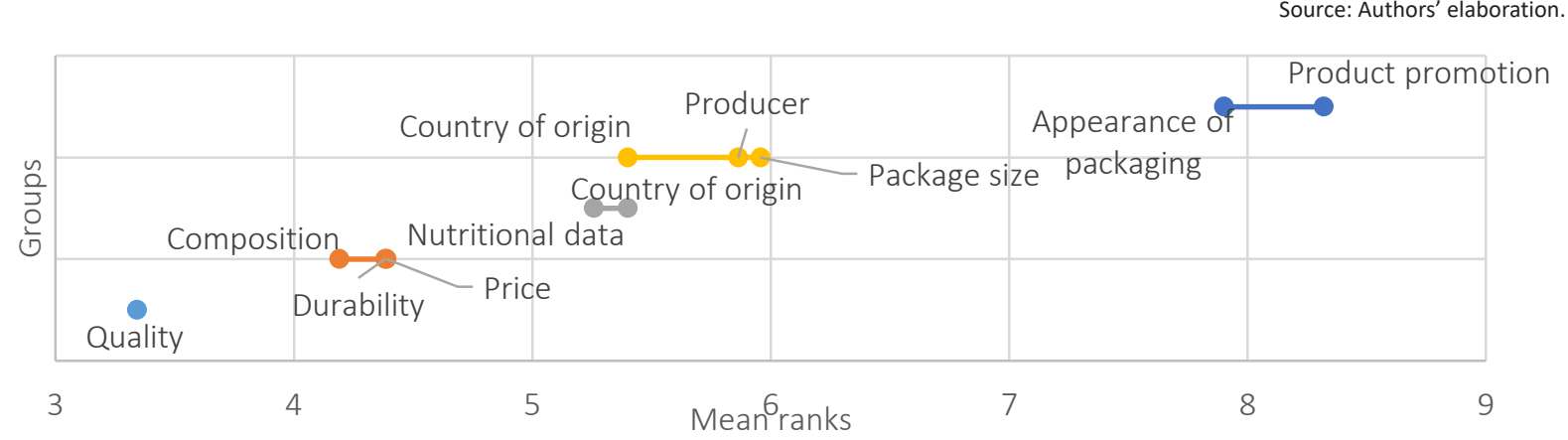

Figure 8. Differences in the assessment of factors determining the level of consumption of milk and dairy products

D. Consumers are not influenced by the package appearance and product promotion related to individual dairy products (Group E). The division of factors into mentioned groups points to differences in the evaluation of individual criteria (groups) by consumers (Figure 8 ).

Subsequently, differences in the evaluation of the factors between individual segments were identified. It can be stated that differences in the importance of factors determining the consumption were statistically demonstrated by the Friedman test ( $\mathrm{p}$-value $=<0.0001$ ) and the Nemenyi method (Table A7, Appendix A). It can be concluded that the first and second segments evaluate quality, composition, durability, and price as the most important factors. The third segment evaluated the price as the second most important factor, which can be attributed to the consumption of dairy products with high added value. An interesting finding was that the similarity of the second and third segments identified for the least important factors (product promotion, packaging appearance, package size, producer, nutritional information, and country of origin) was determined identically. On the contrary, for the first segment of consumers, the packaging appearance, producer, or country of origin are not so important factors, apart from the product promotion. This can be justified in particular by the consumption of various dairy products. At present, the range of dairy products in commercial operations also consists of foreign products, whose offer is more extensive and the price is more favorable, which means that for the Slovak consumer the producer or the country becomes the less important factor. Furthermore, it can be emphasized that in terms of assessing the importance of factors, 4 groups of factors were created in the first segment, 6 groups in the second segment, and 5 groups in the third segment. From the stated above it can be concluded that consumers evaluate the importance of factors differently within individual segments.

\section{CONCLUSION}

The paper is aimed at mapping the situation with milk and dairy products in Slovakia and its comparison with other V4 countries. Based on the analyzed data, it is stated that consumption is low in Slovakia and Hungary, but in the Czech Republic and Poland consumption is recorded in the range of recommended doses. Looking to the future, it is assumed that the situation in Slovakia will be accompanied by unfavorable developments and Slovak consumers will consume the least milk and dairy products compared to other V4 countries. This may be related to the situation resulting from the COVID-19, lower consumer disposable income, preference for other food groups, or alternative diets.

The survey and results presented in the paper provide a new perspective on milk and dairy products consumption, especially in the area of segmentation and creation of three segments depending on the actual level of consumption. The first segment is characterized by consumption slightly below the level of recommended doses, preference of dairy products consumption. Moreover, taste and rational diet are 
the main reason for consumption. Factors determining the level of consumption include quality, composition, durability, and price of products. The second segment is characterized by a sufficient level of consumption and preference for the consumption of milk and dairy products. The investigated segment is characterized by similar consumer behavior because the main reasons for consumption are taste and rationality and the main factors determining the level of consumption are quality, composition, durability, and price. The third segment is the weakest in consumption, as more than $70 \%$ of consumers do not reach the recommended consumption interval, but consumers are characterized by a high preference for consumption of sour-milk and other dairy products. The main reason for consumption is taste and the key factors determining the level of consumption are the quality and price. This also results in differences between individual segments, which were demonstrated by statistical tests.

In this context, it is necessary to appeal to consumers and emphasize the health effects of consumption, with an emphasis on sour-milk products and value-added products. By comparing the situation in milk and dairy consumption in the V4 countries and evaluating the results of the survey with an emphasis on the creation of segments based on the real amount of consumption, the aim of the paper was met. The paper becomes a relevant scientific basis for the needs of scientific expertise and by its nature fills the absent gap in the question of the amount of consumption and creation of segments in the scientific sphere.

\section{AUTHOR CONTRIBUTIONS}

Conceptualization: Lubica Kubicová, Kristína Predanócyová, Peter Šedík.

Data curation: Lubica Kubicová, Kristína Predanócyová, Peter Šedík, Luboš Smutka, Zdenka Kádeková, Ingrida Košičiarová.

Funding acquisition: Luboš Smutka.

Formal analysis: Peter Šedík, Zdenka Kádeková, Ingrida Košičiarová.

Investigation: Lubica Kubicová, Kristína Predanócyová, Peter Šedík, Zdenka Kádeková, Ingrida

Košičiarová.

Methodology: L’ubica Kubicová, Kritína Predanócyová, Peter Šedík, Luboš Smutka, Zdenka Kádeková, Ingrida Košičiarová.

Project administration: L'uboš Smutka, Zdenka Kádeková.

Resources: Lubica Kubicová, Kristína Predanócyová.

Software: Kristína Predanócyová, Peter Šedík.

Supervision: Lubica Kubicová.

Validation: Kristína Predanócyová, Peter Šedík.

Visualization: Zdenka Kádeková, Ingrida Košičiarová.

Writing - original draft: Lubica Kubicová, Kristína Predanócyová, Peter Šedík, Luboš Smutka, Zdenka

Kádeková, Ingrida Košičiarová.

Writing - review \& editing: Lubica Kubicová, Kristína Predanócyová, Zdenka Kádeková.

\section{ACKNOWLEDGMENT}

This paper is supported by the Operational Program Integrated Infrastructure within the project: Demand-driven research for the sustainable and innovative food, Drive4SIFood 313011V336, cofinanced by the European Regional Development Fund.

\section{REFERENCES}

1. Ahmadi Kaliji, S., Mojaverian, S. M., Amirnejad, H., \& Canavari, M. (2019). Factors Affecting Consumers' Dairy Products Pref- erences. AGRIS on-line Papers in Economics and Informatics, 11(2), 3-11. https://doi.org/10.7160/ aol.2019.110201
2. Alwis, A., Edirisinghe, J., \& Athauda, A. (2009). Analysis of Factors Affecting Fresh Milk Consumption Among the Mid-Country 
Consumers. Tropical Agricultural Research and Extension, 12(2), 103-109. https://doi.org/10.4038/ tare.v12i2.2799

3. Bielik, P., Adamičková, I. Bellérová, B., Benda Prokeinová, R., Beňuš, O., Bullová, T., Hallová, M., Hanová, M., Heijman, W., Horská, E., Hrdá, V., Kádeková, Z., Kadlečíková, M., Kapsdorferová, Z., Kapustová, Z., Krajčírová R., Moravčíková, D., Nagyová, L., Neomániová, K., Palšová L., Paluchová, J., Rajčániová, M., Strápeková, Z., Švikruhová, P., Tóth, M. \& Turčeková, N. (2020). Agribusiness \& commerce (2 $2^{\text {nd }}$ ed.). Nitra: Slovak University of Agriculture.

4. Boniface, B., Gyau, A., \& Stringer, R. (2012). Linking price satisfaction and business performance in Malaysia's dairy industry. Asia $\mathrm{Pa}$ cific Journal of Marketing and Logistics, 24(2), 288-304. https://doi. org/10.1108/13555851211218066

5. Bonjour, J.-P. (2005). Dietary protein: an essential nutrient for bone health. Journal of the American College of Nutrition, 24(sup6), 526S-536S. https://doi.org/10.1080 /07315724.2005.10719501

6. Dror, D. K., \& Allen, L. H. (2014). Dairy product intake in children and adolescents in developed countries: trends, nutritional contribution, and a review of association with health outcomes. Nutrition reviews, 72(2), 68-81. https:// doi.org/10.1111/nure.12078

7. Džupina, M., Hodinková, D., \& Kiková, H. (2016). Spoločensky zodpovedné podnikanie ako zdroj hodnôt značky [Corporate social responsibility as a source of brand value]. Nitra: UKF. (In Slovak).

8. Finete, V. L. M., Gouvêa, M. M., Marques, F. F. C., \& Netto, A. D. P. (2013). Is it possible to screen for milk or whey protein adulteration with melamine, urea and ammonium sulphate, combining Kjeldahl and classical spectrophotometric methods? Food Chemistry, 141(4), 3649-3655. https://doi.org/10.1016/j.foodchem.2013.06.046

9. Gambelli, L. (2017). Milk and Its Sugar-Lactose: A Picture of Evaluation Methodologies. Beverages,
3(3), 35. https://doi.org/10.3390/ beverages3030035

10. Garcia, S. N., Osburn, B. I., \& Cullor, J. S. (2019). A one health perspective on dairy production and dairy food safety. One Health, 7, 100086. https://doi.org/10.1016/j. onehlt.2019.100086

11. Gasmalla, M. A., Tessema, H. A., Salaheldin, A., Alahmad, K. Hassanin, H. A. M., \& Aboshora, W. (2017). Health Benefits of Milk and Functional Dairy Products. MOJ Food Processing \& Technology, 4(4), 108-111. https://doi.org/10.15406/mojfpt.2017.04.00099

12. Górska-Warsewicz, H., Rejman, K., Laskowski, W., \& Czeczotko, M. (2019). Milk and Dairy Products and Their Nutritional Contribution to the Average Polish Diet. Nutrients, 11(8), 1771. https://doi. org/10.3390/nu11081771

13. Grebitus, C., Yue, Ch., Bruhn, M., \& Jensen, H. (2007). Milk-Marketing: Impact of Perceived Quality on Consumption Patterns. 105th EAAE Seminar 'International Marketing and International Trade of Quality Food Products'. Bologna, Italy. http://dx.doi.org/10.22004/ ag.econ.7867

14. Guetouache, M., Guessas, B., \& Medjekal, S. (2014). Composition and nutritional value of raw milk. Issues in Biological Sciences and Pharmaceutical Research, 2(10), 115-122. https://doi.org/10.15739/ ibspr.005

15. Guiné, R. P. F., Florença, S. G., Carpes, S., \& Anjos, O. (2020). Study of the Influence of Sociodemographic and Lifestyle Factors on Consumption of Dairy Products: Preliminary Study in Portugal and Brazil. Foods, 9(12), 1775. https://doi.org/10.3390/ foods 9121775

16. Haas, R., Schnepps, A., Pichler, A., \& Meixner, O. (2019). Cow Milk versus Plant-Based Milk Substitutes: A Comparison of Product Image and Motivational Structure of Consumption. Sustainability, 11(18), 5046. https://doi. org/10.3390/su11185046
17. Horská, E., Petrilák, M., Šedík, P., \& Nagyová, L. (2020). Factors Influencing the Sale of Local Products through Short Supply Chains: A Case of Family Dairy Farms in Slovakia. Sustainability, 12(20), 12. https://doi.org/10.3390/ su12208499

18. Hungarian Central Statistical Office. (2020). Per capita amount of available food and nutrients. Retrieved from http://www.ksh. $\mathrm{hu} /$ docs/eng/xstadat/xstadat_ annual/i_qpt011b.html

19. Janecká, M., Homolka, J., Hošková, P., Mach, J., \& Dvořák, M. (2019). Evaluation of Economic Efficiency of Selected Branch in Animal Production in EU and CR. AGRIS on-line Papers in Economics and Informatics, 11(4), 15-30. https:// doi.org/10.7160/aol.2019.110402

20. Jesus, C., Feder, D., \& Peres, M. (2013). The Role of Vitamin D in Pathophysiology and Treatment of Fibromyalgia. Current Pain and Headache Reports, 17, 355. https:// doi.org/10.1007/s11916-0130355-6

21. Kala, R., Samková, E., Hanuš, O., Pecová, L., Sekmokas, K. \& Riaukienè, D. (2019). Milk Protein Analysis: An Overview of the Methods - Development and Application. Acta Universitatis Agriculturae et Silviculturae Mendelianae Brunensis, 67(1), 345-359. https://doi.org/10.11118 actaun201967010345

22. Kanwar, J. R., Kanwar, R. K., Sun, X., Punj, V., Matta, H., Morley, S. M., Parratt, A., Puri, M., \& Sehgal, R. (2009). Molecular and biotechnological advances in milk proteins in relation to human health. Current Protein \& Peptide Science, 10(4), 308-338. https://doi. org/10.2174/138920309788922234

23. Kapaj, A. (2018). Factors that Influence Milk Consumption World Trends and Facts. European Journal of Business, Economics and Accountancy, 6(2), 14-18. Retrieved from https://www.idpublications. org/wp-content/uploads/2018/03/ Full-Paper-FACTORS-THATINFLUENCE-MILK-CONSUMPTION-WORLD-TRENDS-ANDFACTS.pdf 
24. Keresteš, J. (2016). Mlieko vo výžive ludí [Milk in human nutrition]. Bratislava, Slovak Republic: Cad Press. (In Slovak).

25. Kharin, S. (2019). Horizontal Price Transmission on the Russian Dairy Market: Nonlinear Approach. AGRIS on-line Papers in Economics and Informatics, 11(3), 45-54. https://doi.org/10.7160/ aol.2019.110305

26. Központi Statisztikai Hivatal (KSH). (2019). Statisztikai Tükör: Élelmiszerkínálat, 2017. (In Hungarian). Retrieved from http:// www.ksh.hu/docs/hun/xftp/stattukor/elelmfogy/elelmfogy17.pdf

27. Központi Statisztikai Hivatal (KSH). (2020). Magyar Statisztikai Zsebkönyv, 2019. (In Hungarian). Retrieved from https://mave.hu/ uploads/Zsebkonyv_2019_ELEKTORNIKUS.pdf

28. Krivošíková, A., Nagyová, L., Kubeláková, A., \& Mokrý, S. (2019). Consumer preferences on milk market: evidence from Slovak Republic. Potravinárstvo, 13(1), 961-970. https://doi.org/10.5219/1221

29. Król, J., Wawryniuk, A., Brodziak, A., Barłowska, J., \& Kuczyńska, B. (2020). The Effect of Selected Factors on the Content of Fat-Soluble Vitamins and Macro-Elements in Raw Milk from HolsteinFriesian and Simmental Cows and Acid Curd Cheese (Tvarog). Animals, 10(10), 1800. https://doi. org/10.3390/ani10101800

30. Kubicová, L., Predanocyová, K., \& Kádeková, Z. (2019). Factors Affecting the Demand for Milk and Dairy Products in the Slovak Republic. AGRIS on-line Papers in Economics and Informatics, 11(4), 39-47. https://doi.org/10.7160/ aol.2019.110404

31. Kurajdová, K., TáboreckáPetrovičová, J., \& Kaščáková, A. (2015). Factors Influencing Milk Consumption and Purchase Behavior - Evidence from Slovakia. Procedia Economics and Finance, 34, 573-580. https://doi.org/10.1016/S22125671(15)01670-6

32. Maitah, M., \& Smutka, L. (2012). Economic analysis of milk production and consumption in the middle East and North Africa. Acta Universitatis Agriculturae Et Silviculturae Mendelianae Brunensis, 60(4), 245-254. https://doi.org/10.11118/actaun201260040245

33. Månsson, H. L. (2008). Fatty acids in bovine milk fat. Food \& Nutrition Research, 52. https://doi. org/10.3402/fnr.v52i0.1821

34. Matulová, K., Bubáková, P., Škubna, O., \& Taussigová, T. (2010). Econometric Analysis of Milk Value Chain. AGRIS on-line Papers in Economics and Informatics, 2(4), 51-61. Retrieved from https://online.agris.cz/files/2010/ agris_on-line_2010_4_special_matulova_bubakova_skubna_ taussigova.pdf

35. Medhammar, E., WijesinhaBettoni, R., Stadlmayr, B., Nilsson, E., Charrondiere, R. U., \& Burlingame, B. (2012). Composition of milk from minor dairy animals and buffalo breeds from a biodiversity perspective. Journal of the Science of Food and Agriculture, 92(3), 445-474. https://doi. org/10.1002/jsfa.4690

36. Michaelsen, K. F., Nielsen, A.-L. H., Roos, N., Friis, H., \& Molgaard C. (2011). Milk and Milk Products in Human Nutrition. In R. A. Clemens, O. Hernell, \& K. F. Michaelsen (Eds.), Nestlé Nutrition Institute Workshop Series Pediatric Program, 67, 99-111. https://doi. org/10.1159/000325578

37. Moore, L. L., Singer, M. R., Bradlee, M. L. Djoussé, L., Proctor, M. H., Cupples, L. A., \& Ellison, R. C. (2005). Intake of fruits, vegetables, and dairy products in early childhood and subsequent blood pressure change. Epidemiology, 16(1), 4-11. https://doi.org/10.1097/01. ede.0000147106.32027.3e

38. Muehlho, E., Bennett, A., \& Mcmahon, D. (2013). Milk and Dairy Products in Human Nutrition. Rome: Food and Agriculture Organization of the United Nations. Retrieved from http://www.fao. org/3/i3396e/i3396e.pdf

39. Nagyová, L'., Horská, E., Kačániová, M., Čanigová, M., Zeleňáková, L., Štefániková, J.,
Ducková, V., Zajác, P., Benešová, L., Čapla, J., Poláková, Z., Obtulovič, P., Berčík, J., Vietoris, V., Paluchová, J., Rybanská, J., Petril'ák, M., Géci, A., \& Krivošíková, A. (2020). Metodika výskumu kvalitatívnych ukazovatel'ov produktu a miesta predaja: zamerané na malých a stredných výrobcov mlieka a syrov a predaj na farme. Nitra: Slovenská pol'nohospodárska univerzita. (In Slovak).

40. Nicklas, T. A., O’Neil, C. E., \& Fulgoni, V. L. (2009). The role of dairy in meeting the recommendations for shortfall nutrients in the American diet. Journal of the American College of Nutrition, 28(sup1), 73S-81S. https://doi.org/ 10.1080/07315724.2009.10719807

41. Pereira, P. C. (2014). Milk Nutritional Composition and Its Role in Human Health. Nutrition, 30(6), 619-627. http://dx.doi. org/10.1016/j.nut.2013.10.011

42. Pfeuffer, M., \& Watzl, B. (2018). Nutrition and health aspects of milk and dairy products and their ingredients. Ernahrungs Umschau, 65(2), 22-33. https://doi. org/10.4455/eu.2018.006

43. Polakevičová, I. (2015). Application of transactional analysis in marketing research - models of the hierarchy of effects of marketing communication and structural analysis. Prohuman, 7(2), 1-10. Retrieved from https:// www.prohuman.sk/psychologia/ application-transactional-analysismarketing

44. Prentice, A. M. (2014). Dairy products in global public health. The American Journal of Clinical Nutrition, 99(5), 1212S1216S. https://doi.org/10.3945/ ajcn.113.073437

45. Rizzoli, R. (2014). Dairy products, yogurts, and bone health. The American Journal of Clinical Nutrition, 99(5), 1256S-1262S. https:// doi.org/10.3945/ajen.113.073056

46. Rozenberg, S., Body, J. J., Bruyère, O., Bergmann, P., Brandi, M. L., Cooper, C., Devogelaer, J.-P., Gielen, E., Goemaere, S., Kaufman, J.-M., Rizzoli, R., \& Reginster, J.-Y. (2016). Effects of Dairy Products 
Consumption on Health: Benefits and Beliefs-A Commentary from the Belgian Bone Club and the European Society for Clinical and Economic Aspects of Osteoporosis, Osteoarthritis and Musculoskeletal Diseases. Calcified Tissue International, 98(1), 1-17. https:// doi.org/10.1007/s00223-0150062-x

47. Smutka, L., Rovný, P., \& Hambálková, M. (2016). Foreign trade with agricultural products in the Slovak Republic. International Scientific Days 2016. The agri-food value chain: challenges for natural resources management and society, 68-74. http://dx.doi.org/10.15414/ isd2016.s1.06

48. Špička, J. (2013). The Competitive Environment in the Dairy Industry and its Impact on the Food Industry. AGRIS on-line Papers in Economics and Informatics, 5(2), 89-102. http://dx.doi. org/10.22004/ag.econ.152693

49. Statistical Office of the Czech Republic. (2021). Spotreba potravin 1948 až 2019 v grafech. (In Czech). Retrieved from https://www.czso. $\mathrm{cz} / \mathrm{csu} / \mathrm{xj} /$ spotreba-potravin1948-az-2019-v-grafech
50. Statistical Office of the Slovak Republic. (2020). Databases. Retrieved from https://slovak.statistics.sk/wps/portal/ext/Databases

51. Statistics Poland. (2021). Rocznik Statystyczny Rolnictwa 2020. (In Polish). Retrieved from https:// stat.gov.pl/obszary-tematyczne/ roczniki-statystyczne/rocznikistatystyczne/rocznik-statystycznyrolnictwa-2020,6,14.html

52. Thorning, T., Raben, A., Tholstrup, T., Soedamah-Muthu, S., Givens, I., \& Astrup, A. (2016). Milk and dairy products: Good or bad for human health? An assessment of the totality of scientific evidence. Food \& Nutrition Research, 60. https://doi.org/10.3402/fnr. v60.32527

53. Visioli, F., \& Strata, A. (2014). Milk, dairy products, and their functional effects in humans: A narrative review of recent evidence. Advances in Nutrition, 5(2), 131-143. https://doi.org/10.3945/ an.113.005025

54. Willett, W. C., \& Ludwig, D. S. (2020). Milk and Health. The New England Journal of Medicine, 382(7),
644-654. https://doi.org/10.1056/ NEJMra1903547

55. Xu, L., Yang, X., \& Wu, L. (2019). Consumers' Willingness to Pay for Imported Milk: Based on Shanghai, China. International Journal of Environmental Research and Public Health, 17(1), 244. https://doi. org/10.3390/ijerph17010244

56. Žáková Kroupová, Z., Hálová, P., \& Rumánková, L. (2020). Productivity of Czech Milk Production in European Comparison. AGRIS on-line Papers in Economics and Informatics, 12(3), 115-127. https://doi. org/10.7160/aol.2020.120310

57. Zamberlin, S., Antunac, N., Havranek, J., \& Samaržija, D. (2012). Mineral elements in milk and dairy products. Mljekarstvo, 62(2), 111-125. Retrieved from https://hrcak.srce.hr/file/124024

58. Zemel, M. B., Thompson, W., Milstead, A., Morris, K., \& Campbell, P. (2004). Calcium and dairy acceleration of weight and fat loss during energy restriction in obese adults. Obesity Research, 12(4), 582-590. https://doi. org/10.1038/oby.2004.67 


\section{APPENDIX A}

Table A1. Composition of cow's milk (per $100 \mathrm{~g}$ of cow's milk)

Source: Medhammar et al. (2012).

\begin{tabular}{l|c|c}
\hline \multicolumn{1}{c|}{ Ingredient } & Average & Range \\
\hline Water & $87.8 \mathrm{~g}$ & $87.3-88.1 \mathrm{~g}$ \\
\hline Milk protein & $3.3 \mathrm{~g}$ & $3.2-3.4 \mathrm{~g}$ \\
Lactose & $4.7 \mathrm{~g}$ & $4.5-5.1 \mathrm{~g}$ \\
Milk fat & $3.3 \mathrm{~g}$ & $3.1-3.3 \mathrm{~g}$ \\
Minerals & $0.7 \mathrm{~g}$ & $0.7-0.7 \mathrm{~g}$ \\
\hline
\end{tabular}

Table A2. Structure of respondents involved in the consumer survey

Source: Authors' elaboration.

\begin{tabular}{|c|c|c|c|c|c|}
\hline \multicolumn{2}{|c|}{ Categories } & \multirow{2}{*}{$\frac{\%}{64.3}$} & \multicolumn{2}{|c|}{ Categories } & $\%$ \\
\hline \multirow{2}{*}{ Gender } & Women & & \multirow{3}{*}{$\begin{array}{l}\text { Monthly income of the } \\
\text { household }\end{array}$} & Less than 1,000 EUR & 20.1 \\
\hline & Men & 35.7 & & $1,001-2,000$ EUR & 54.4 \\
\hline \multirow{4}{*}{ Age } & Up to 25 years & 43.1 & & More than 2,001 EUR & 25.5 \\
\hline & $26-35$ years & 23.2 & \multirow{4}{*}{$\begin{array}{l}\text { Number of members in } \\
\text { households }\end{array}$} & $1-2$ members & 22.3 \\
\hline & $36-50$ years & 19.1 & & 3 members & 23.2 \\
\hline & More than 51 years & 14.7 & & 4 members & 37.5 \\
\hline \multirow{3}{*}{ Education } & Elementary & 1.9 & & 5 members and more & 17.0 \\
\hline & Secondary & 45.8 & \multirow{7}{*}{ Economic status } & Student & 36.3 \\
\hline & University & 52.3 & & Employed & 48.1 \\
\hline \multirow{2}{*}{ Permanent residence } & Village & 48.8 & & Self-employed & 4.6 \\
\hline & City & 51.2 & & Unemployed & 1.2 \\
\hline \multirow{3}{*}{$\begin{array}{l}\text { Monthly income } \\
\text { of respondents }\end{array}$} & Less than 400 EUR & 39.6 & & Maternity leave & 2.9 \\
\hline & $401-800$ EUR & 39.4 & & \multirow{2}{*}{ Pensioner } & \multirow{2}{*}{6.9} \\
\hline & More than 801 EUR & 21.0 & & & \\
\hline
\end{tabular}

Table A3. Consumption of milk and dairy products in individual segments

Source: Authors' elaboration.

\begin{tabular}{|c|c|c|c|}
\hline Segments & 1 Segment & 2 Segment & 3 Segment \\
\hline$\%$ of total respondents & $34.7 \%$ & $25.9 \%$ & $39.4 \%$ \\
\hline \multicolumn{4}{|c|}{ Total consumption of milk and dairy products } \\
\hline $221 \mathrm{~kg} /$ year and more & $19.4 \%$ & $14.2 \%$ & $10.8 \%$ \\
\hline 206 kg/year - 220 kg/year & $25.6 \%$ & $83.6 \%$ & $13.2 \%$ \\
\hline Less than 206 kg/year & $55.0 \%$ & $2.2 \%$ & $76.0 \%$ \\
\hline \multicolumn{4}{|c|}{ Consumption of drinking milk } \\
\hline $91 \mathrm{~kg} / \mathrm{year}$ and more & $0.0 \%$ & $100.0 \%$ & $28.9 \%$ \\
\hline Less than $91 \mathrm{~kg} /$ year & $100.0 \%$ & $0.0 \%$ & $71.1 \%$ \\
\hline \multicolumn{4}{|c|}{ Cheese consumption } \\
\hline $6.9 \mathrm{~kg} /$ year and more & $100.0 \%$ & $100.0 \%$ & $84.8 \%$ \\
\hline Less than $6.9 \mathrm{~kg} /$ year & $0.0 \%$ & $0.0 \%$ & $15.2 \%$ \\
\hline \multicolumn{4}{|c|}{ Consumption of curds } \\
\hline $3.2 \mathrm{~kg} /$ year and more & $100.0 \%$ & $100.0 \%$ & $11.8 \%$ \\
\hline Less than $3.2 \mathrm{~kg} /$ year & $0.0 \%$ & $0.0 \%$ & $88.2 \%$ \\
\hline \multicolumn{4}{|c|}{ Consumption of sour-milk and other dairy products } \\
\hline $16 \mathrm{~kg} /$ year and more & $100.0 \%$ & $100.0 \%$ & $77.5 \%$ \\
\hline Less than 16 kg/year & $0.0 \%$ & $0.0 \%$ & $22.5 \%$ \\
\hline
\end{tabular}


Table A4. Demographic structure of consumers by segments

Source: Authors' elaboration.

\begin{tabular}{|c|c|c|c|c|}
\hline & 1 Segment & 2 Segment & 3 Segment & p-value \\
\hline \multicolumn{5}{|c|}{ Gender } \\
\hline Man & $32.8 \%$ & $38.8 \%$ & $36.3 \%$ & \multirow{2}{*}{0.532} \\
\hline Woman & $67.2 \%$ & $61.2 \%$ & $63.7 \%$ & \\
\hline \multicolumn{5}{|c|}{ Age } \\
\hline Up to 25 years & $40.6 \%$ & $43.3 \%$ & $45.1 \%$ & \multirow{3}{*}{0.683} \\
\hline $26-50$ years & $43.9 \%$ & $39.6 \%$ & $42.6 \%$ & \\
\hline More than 51 years & $15.6 \%$ & $17.2 \%$ & $12.3 \%$ & \\
\hline \multicolumn{5}{|c|}{ Education } \\
\hline Tertiary & $50.0 \%$ & $47.0 \%$ & $41.7 \%$ & \multirow{3}{*}{0.494} \\
\hline Secondary & $47.8 \%$ & $51.5 \%$ & $56.9 \%$ & \\
\hline Primary & $2.2 \%$ & $1.5 \%$ & $1.5 \%$ & \\
\hline \multicolumn{5}{|c|}{ Permanent residence } \\
\hline Urban & $49.4 \%$ & $53.7 \%$ & $51.0 \%$ & \multirow{2}{*}{0.752} \\
\hline Rural & $50.6 \%$ & $46.3 \%$ & $49.0 \%$ & \\
\hline \multicolumn{5}{|c|}{ Number of household members } \\
\hline 1 & $2.2 \%$ & $1.5 \%$ & $6.4 \%$ & \multirow{5}{*}{0.036} \\
\hline 2 & $20.6 \%$ & $19.4 \%$ & $16.7 \%$ & \\
\hline 3 & $23.3 \%$ & $23.9 \%$ & $22 \%$ & \\
\hline 4 & $37.8 \%$ & $30.6 \%$ & $41.7 \%$ & \\
\hline 5 & $12.8 \%$ & $15.7 \%$ & $8.8 \%$ & \\
\hline \multicolumn{5}{|c|}{ Economic status } \\
\hline Self-employed & $3.9 \%$ & $7.5 \%$ & $3.4 \%$ & \multirow{6}{*}{0.337} \\
\hline Retired & $6.1 \%$ & $9.0 \%$ & $6.4 \%$ & \\
\hline Maternity leave & $5.0 \%$ & $1.5 \%$ & $2.0 \%$ & \\
\hline Unemployed & $1.1 \%$ & $0.7 \%$ & $1.5 \%$ & \\
\hline Employed & $51.7 \%$ & $43.3 \%$ & $48.0 \%$ & \\
\hline Student & $32.2 \%$ & $38.1 \%$ & $38.7 \%$ & \\
\hline \multicolumn{5}{|c|}{ Respondent's income } \\
\hline Up to 400 euros & $33.3 \%$ & $41.0 \%$ & $44.1 \%$ & \multirow{3}{*}{0.336} \\
\hline $401-1,200$ euros & $63.3 \%$ & $53.0 \%$ & $49.5 \%$ & \\
\hline More than 1,201 euros & $3.3 \%$ & $6.0 \%$ & $6.4 \%$ & \\
\hline \multicolumn{5}{|c|}{ Household income } \\
\hline Up to 1,000 euros & $18.9 \%$ & $22.4 \%$ & $19.6 \%$ & \multirow{3}{*}{0.216} \\
\hline $1,001-2,000$ euros & $54.4 \%$ & $47.0 \%$ & $59.3 \%$ & \\
\hline More than 2,001 euros & $26.7 \%$ & $30.6 \%$ & $21.1 \%$ & \\
\hline
\end{tabular}

Table A5. Reasons for consumption and respect for consumer health principles in individual segments

\begin{tabular}{l|c|c|c|c}
\hline \multicolumn{1}{c}{ Reason for consumption } & 1 Segment & 2 Segment & 3 Segment & p-value \\
\hline High level of nutritional value & $17.8 \%$ & $12.7 \%$ & $11.3 \%$ \\
Habit since childhood & $11.1 \%$ & $6.7 \%$ & $18.1 \%$ \\
I like to consume them, I like the taste & $45.6 \%$ & $56.7 \%$ & $49.5 \%$ \\
Part of a rational diet & $21.1 \%$ & $23.1 \%$ & $17.6 \%$ \\
Other & $4.4 \%$ & $0.7 \%$ & $3.4 \%$ & 016 \\
\hline
\end{tabular}


Table A6. Factor loadings from Categorical Principal Component Analysis (CATPCA)

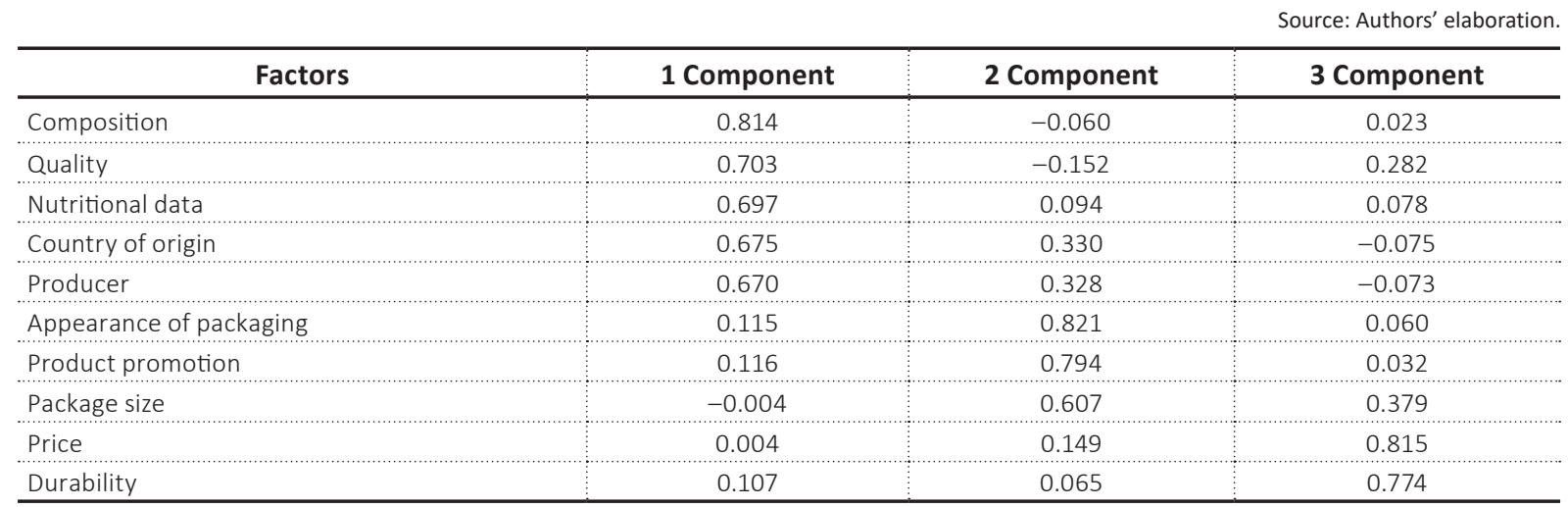

Table A7. Differences in the assessment of factors determining the level of consumption of milk and dairy products by segment

Source: Authors' elaboration.

\begin{tabular}{|c|c|c|c|c|c|c|c|c|c|}
\hline Segment & Sample & Mean of ranks & \multicolumn{6}{|c|}{ Groups } & Importance of factor \\
\hline \multirow{10}{*}{1 Segment } & Quality & 3.492 & A & - & - & - & - & - & Most important \\
\hline & Composition & 4.103 & A & - & - & - & - & - & - \\
\hline & Durability & 4.378 & A & B & - & - & - & - & - \\
\hline & Price & 4.422 & A & $B$ & - & - & - & - & - \\
\hline & Nutritional data & 5.211 & - & B & C & - & - & - & - \\
\hline & Package size & 5.764 & - & - & C & - & - & - & - \\
\hline & Country of origin & 5.811 & - & - & C & - & - & - & - \\
\hline & Producer & 6.028 & - & - & C & - & - & - & - \\
\hline & Appearance of packaging & 7.753 & - & - & - & $\mathrm{D}$ & - & - & - \\
\hline & Product promotion & 8.039 & - & - & - & $\mathrm{D}$ & - & - & Least important \\
\hline \multirow{10}{*}{2 Segment } & Quality & 3.354 & A & - & - & - & - & - & Most important \\
\hline & Composition & 4.019 & A & B & - & - & - & - & - \\
\hline & Durability & 4.597 & - & B & C & - & - & - & - \\
\hline & Price & 4.634 & - & B & C & D & - & - & - \\
\hline & Country of origin & 5.015 & - & B & C & D & - & - & \\
\hline & Nutritional data & 5.209 & - & - & C & $\mathrm{D}$ & $E$ & - & - \\
\hline & Producer & 5.799 & - & - & - & $\mathrm{D}$ & $E$ & - & - \\
\hline & Package size & 6.220 & - & - & - & - & $E$ & - & - \\
\hline & Appearance of packaging & 7.940 & - & - & - & - & - & $\mathrm{F}$ & - \\
\hline & Product promotion & 8.213 & - & - & - & - & - & $\mathrm{F}$ & Least important \\
\hline \multirow{10}{*}{3 Segment } & Quality & 3.199 & A & - & - & - & - & - & Most important \\
\hline & Price & 4.196 & - & B & - & - & - & - & - \\
\hline & Durability & 4.245 & - & B & - & - & - & - & - \\
\hline & Composition & 4.380 & - & B & C & - & - & & - \\
\hline & Country of origin & 5.292 & - & - & C & $\mathrm{D}$ & - & - & - \\
\hline & Nutritional data & 5.331 & - & - & - & $\mathrm{D}$ & - & - & - \\
\hline & Producer & 5.762 & - & - & - & $D$ & - & - & - \\
\hline & Package size & 5.953 & - & - & - & $\mathrm{D}$ & - & - & - \\
\hline & Appearance of packaging & 8.007 & - & - & - & - & $E$ & - & - \\
\hline & Product promotion & 8.635 & - & - & - & - & $E$ & - & Least important \\
\hline
\end{tabular}

